\title{
The Association of Early Childhood Education and Care with Cognitive Learning Outcomes at 15 Years of Age in Finland
}

\author{
Aino Saarinen",2*, Jari Lipsanen2 ${ }^{2}$, Minna Huotilainen ${ }^{3}$, Mirka Hintsanen1, \\ Liisa Keltikangas-Järvinen²
}

${ }^{1}$ Research Unit of Psychology, University of Oulu, Oulu, Finland

${ }^{2}$ Department of Psychology and Logopedics, Faculty of Medicine, University of Helsinki, Helsinki, Finland

${ }^{3}$ Faculty of Educational Sciences, University of Helsinki, Helsinki, Finland

Email: *aino.i.saarin en@helsinki.fi

How to cite this paper: Saarinen, A., Lipsanen, J., Huotilainen, M., Hintsanen, M., \& Keltikangas-Järvinen, L. (2019). The Association of Early Childhood Education and Care with Cognitive Learning Outcomes at 15 Years of Age in Finland. Psychology, 10, 500-520.

https://doi.org/10.4236/psych.2019.104033

Received: February 6, 2019

Accepted: March 11, 2019

Published: March 14, 2019

Copyright () 2019 by author(s) and Scientific Research Publishing Inc. This work is licensed under the Creative Commons Attribution International License (CC BY 4.0).

http://creativecommons.org/licenses/by/4.0/

\begin{abstract}
Background: We investigated whether child's participation in early childhood education and care (ECEC) is associated with later cognitive learning outcomes at 15 years of age in Finland. Methods: The Finnish PISA 2015 data $(N=4634)$ was used. Learning outcomes in science, reading, mathematics, and collaborative problem-solving were evaluated with computer-based tests in 2015. Participation in ECEC and parental SES were assessed with questionnaires. Results: In any learning outcome, students who had only participated in preschool at 6 years of age did not differ from students who had started in ECEC at any other age between 1 - 5 years. Additionally, at a trend level, participation in ECEC before preschool had more beneficial effects on learning outcomes among students with high parental SES than low parental SES. Conclusions: ECEC before preschool is not associated with learning outcomes at 15 years of age in Finland. ECEC may not have compensatory effects for children coming from socioeconomically disadvantaged families in Finland. In the future, it is necessary to further investigate which factors might diminish the inequality in learning outcomes between children coming from different family background. In particular, more research is needed about the influence of both societal factors (e.g. integration of immigration families, psychosocial family environment, gender-specific factors) and childcare related factors (e.g. special education; individually tailored day care programs for high-risk children).
\end{abstract}

\section{Keywords}

Early Childhood Education, Early Childhood Care, Learning Outcomes, 
PISA, Parental Socioeconomic Status

\section{Introduction}

In the PISA 2003, 2006, and 2009 tests, Finland was ranked among the best countries in all cognitive learning outcomes (Organisation for Economic Cooperation and Development, OECD, 2004, 2006, 2010). This was called even as "the Finnish miracle of PISA" (e.g. Simola, 2005). However, the most recent PISA findings raised severe concerns by demonstrating that the learning outcomes of the Finnish students have declined, particularly in mathematics (OECD, 2016). Moreover, the variance in the learning outcomes has substantially increased in Finland (OECD, 2016). Especially, the role of socioeconomic family background for learning outcomes has increased in Finland, so that students coming from low-SES families have on average lower skills in mathematics, reading, and science than previously (OECD, 2016). This is especially remarkable since one fundamental goal of the Finnish comprehensive school is to provide equal possibilities for school success for all students, regardless of their family backgrounds (e.g. Jakku-Sihvonen \& Kuusela, 2002).

Subsequently, in Finland, the recent PISA findings have stimulated an intense societal debate about how to increase the equality in school outcomes and to reduce the influence of family background on school achievements. Especially, the role of early childhood education and care has been discussed. Specifically, early childhood education is suggested to compensate the scarce resources at home among children coming from socioeconomically disadvantaged families (Salmi, 2012). Further, it has even been proposed that the possibility to receive early childhood education is the child's fundamental right that cannot be denied from the child (Rantalaiho, 2009; Repo, 2010) and that early childhood care "lays the foundation for success in later life" (Määttä \& Uusiautti, 2012). Hence, there has been a demand that a larger percentage of children should be provided with early childhood education and care in the first years of life, based on the argument that this could increase equality in later school achievements (e.g. Hiilamo et al., 2018; Salmi, 2012). Following this societal debate, the Finnish government has decided to enhance children's participation rate in early childhood education and care (Ministry of Education and Culture, 2016). Such extensive economic investments, however, should be firmly based on evidence. Currently, evidence is largely anecdotal on whether participation in early childhood education and care predicts higher school achievements in Finland.

Currently, evidence suggests that participation in early childhood education and care is related to better cognitive achievements in early childhood. For example, it has been found that exposure to early childhood education and care predicts better cognitive performance at 3 years of age (Burchinal et al., 2000), higher language performance at 4.5 years of age (NICHD, 2002a), and better skills in reading and mathematics at school entry (Magnuson et al., 2007). 
Moreover, more time spent in early childhood education is suggested to be related to better memory in the first school years (NICHD, 2005) and higher cognitive abilities at 8 years of age (Broberg et al., 1997). Taken together, there is evidence that participation in early childhood education and care is related to better cognitive performance in short-term outcomes, i.e. in such cognitive tests that mostly measure those skills that are practiced in early childhood education.

Instead, evidence is highly scarce and contradictory whether early childhood education and care predicts later school achievements after the first school years, such as school grades in the comprehensive school or high school or educational level in adulthood (Karhula, Erola, \& Kilpi-Jakonen, 2017; Kosonen \& Huttunen, 2018). Overall, in order to support evidence-based political decisions about education, more research is needed about the effects of early childhood education and care on school achievements after the first school years.

The school system in Finland is practically identical to other Nordic countries and to several other European countries. Specifically, early childhood education takes place during the first 6 years of life. The comprehensive school begins at the age of 7 years and includes the 9 following years. Moreover, the same curriculum is provided for the whole age cohort throughout the comprehensive school. Further, there are several reasons why Finland is a particularly optimal country to investigate the influence of early childhood education on children's later learning outcomes. Firstly, there exist uniform legislative guidelines for the pedagogical and learning goals and the maximum sizes of child groups in all day care centers in Finland (Early Childhood Education (ECE) Legislation, 1973). Hence, the quality of early childhood education is very high and homogeneous over the country. Secondly, there exist academic-level educational programs for both kindergarten and school teachers, ensuring that the level of expertise is highly similar between single teachers. Thirdly, the number of private schools is very low, so that almost all children participate the municipal schools with the same curriculum. Finally, Finland is often considered as a model country due to its high rankings in school evaluations like Pisa. Hence, many European, American and Asian countries are looking to Finland for ideas in developing their own school systems. For this reason, it is of utmost importance that any failures or problems in the Finnish school system are revealed before such model-taking goes any further.

The aim of the present study was to investigate the link of early childhood education and care with cognitive achievements at 15 years of age in Finland. Firstly, we investigated whether participation in early childhood education and care is linked with cognitive learning outcomes in the PISA 2015 test (i.e. reading literacy, mathematical literacy, scientific literacy, and collaborative problem-solving). Secondly, we investigated whether the link of early childhood education and care with cognitive learning outcomes might be modified by parental socioeconomic status. That is, we examined whether participation in early childhood education and care might increase the equality in the learning outcomes between students coming from different socioeconomic family back- 
grounds. We used the PISA 2015 data $(N=4634)$ since it includes a nationally representative sample of the Finnish 15-year-old students born in 2000 and also a highly standardized set of cognitive learning outcomes. The data was analyzed using structural equation models. We hypothesized that students who had participated in early childhood education and care (before 6 years of age) would have better cognitive learning outcomes at 15 years of age, when compared to students who have only participated preschool at 6 years of age. Additionally, we hypothesized that early childhood education and care might have particularly positive effects on learning outcomes in children coming from lower socioeconomic family backgrounds.

\section{Material and Methods}

\subsection{Participants}

The participants were selected from the Finnish PISA (Programme for International Student Assessment) 2015 data. The sampling was conducted in two phases. Firstly, more than 150 national schools that included students within the desired age range were selected (students who were aged between 15 years and 3 months and 16 years and 2 months, and who were at grade 7 or higher). In Finland, this desired target population included 58,955 students (from more than 150 schools). In Finland, this desired target population included 58,955 students (from more than 150 schools). This desired target population was representative of the Finnish population of 15-year-old students with regard to the most important sociodemographic factors. From this target population, some schools were excluded in accordance with the following criteria: schools that were geographically inaccessible; schools that provided education only for a restricted population, such as schools for the blind; and schools where the administration of the PISA assessment was not considered feasible because of practical reasons. In Finland, altogether 472 students were excluded because they were attending such schools that were eventually excluded. Overall, this may not likely have substantially biased the representativeness of the sample. Specifically, students who have attended schools for a restricted population (such as blind) may not likely have participated in ordinary early childhood education. Furthermore, in such school districts that were geographically inaccessible for PISA (e.g. some remote towns in the Lapland), there may not likely have been available ordinary possibilities for participating in early childhood education.

Secondly, from each included school, 42 students within the desired age range were randomly selected. From the selected students, students with an intellectual or functional disability and students with limited assessment language proficiency were excluded. In Finland, 124 students were excluded because of such personal reasons.

Finally, after this selection process, altogether 5882 Finnish students participated in the PISA 2015. In Finland, $0.5 \%$ of the sample were at the 7 th grade, $13.6 \%$ at the 8 th grade, $85.7 \%$ at the 9 th grade, and $0.2 \%$ at the 11 th grade. A 
more detailed description of the sampling and design of the PISA 2015 is available elsewhere (OECD, 2017a).

This study was carried out in line with the Code of Ethics of the World Medical Association (Declaration of Helsinki) that provides ethical guidelines for research involving human subjects (see World Medical Association, 2001).

From the Finnish PISA sample of 5882 students, we excluded all such participants who had missing data on the study variables (early childhood education and care; scientific literacy; mathematical literacy, reading literacy; collaborative problem-solving; age; gender; the index of economic, social, and cultural status). Additionally, students who had not received early childhood education or attended preschool at all $(N=82)$ and students whose parents could not remember their child's starting age at early childhood education $(N=848)$ were excluded from the study sample. Consequently, the final sample in the present study consisted of 4634 students.

\subsection{Measures}

\subsubsection{Early Childhood Education and Care}

Students' participation in early childhood education and care (ISCED $=0$ in accord with the International Standard Classification of Education 1997) was assessed with questionnaires filled by students' parents. Parents were asked about 1) their child's age at entry into early childhood education and care (in years) and 2) the duration of early childhood education and care (in years). In this study, students were classified into 3 categories with regard to their participation in early childhood education and care: 1) preschool at 6 years of age only, 2) preschool at 6 years of age and early childhood education started at 3 - 5 years of age, and 3) preschool at 6 years of age and early childhood care started before 3 years of age. The cut-off age of 3 years has been used also previously (e.g. Mol et al., 2008; Snow et al., 2007).

In Finland, children begin the one-year-long preschool at the age of 6 years. Preschool is compulsory for the Finnish children. The comprehensive school (including the first 9 school years) starts at the age of 7 years. There is the same curriculum for the whole age cohort in the Finnish comprehensive school. In Finland, kindergarten teachers are educated in university faculties, and there must be at least one certified kindergarten teacher in each child group in day-care centers (Early Childhood Education Legislation, 1973/36). Further, there are allowed to be at most 12 children below 3 years in a child group ( $\max 4$ children per caretaker) and at most 24 children aged 3 - 6-years in a child group ( $\max 8$ children per caretaker) in the day-care centers. There are also legal guidelines for room temperature, the noise level of electrical devices, and pedagogical and learning goals in day-care centers. A more detailed description of the Finnish legislation of early childhood education and care is available elsewhere (Early Childhood Education Legislation, 1973/36).

\subsubsection{Cognitive Learning Outcomes}

There were altogether about 810 minutes of test items for science, reading, ma- 
thematics, and collaborative problem solving. The students completed different combinations of the test items. Each student conducted a 2-hour test pattern consisting of four 30-minute clusters: 2 clusters with scientific literacy and the remaining clusters with reading literacy, mathematical literacy, and collaborative problem solving. All the items were conducted using computer-based tests. Each item was answered using one of the following response formats: multiple choice-response (choosing one or more alternatives from a set of responses), closed constructed-response (e.g. writing a single number or word), or open constructed-response (a more extended written response). The measurement of the cognitive learning outcomes is described more precisely elsewhere (OECD, 2017b).

Scientific literacy measured student's knowledge in the major fields of biology, physics, chemistry, and space sciences. Further, it measured student's ability to identify certain scientific concepts (e.g. dependent and independent variable, control variable, measurement error) and to differentiate between scientific hypotheses, observations, and facts.

Mathematical literacy was defined as the ability to formulate the contextualized problems into a mathematical form, perform computations, and interpret mathematical results in a variety of contexts. The items included, for example, mental calculation, spatial visualization, and modeling mathematical change and relationships with appropriate mathematical functions.

Reading literacy referred to student's capacity to understand, interpret, integrate, and reflect the content of a variety of text types. The text types included continuous texts (chapters, books), non-continuous text materials (lists, tables, graphs, advertisements, indexes), and their combinations. The texts were related to personal, occupational, educational, and public contexts in order to evaluate the student's ability to process texts in variety of every-day situations.

Collaborative problem-solving referred to the ability to formulate shared understanding about a problem with others, and to collaborate with others to solve the problem so that each group member's knowledge could be utilized. The items of collaborative problem-solving did not measure students' ability to solve problems per se, but the ability to collaborate with others (Shaw \& Child, 2017). In the PISA 2015, collaborative problem-solving was measured with computer-based items, where each student was collaborating with computer agents.

A more detailed description of the assessment of mathematical literacy, scientific literacy, reading literacy, and collaborative problem-solving is available elsewhere (OECD, 2017b).

\subsubsection{The Index of Economic, Social, and Cultural Status (ESCS)}

Parental socioeconomic status was evaluated with the index of economic, social, and cultural status (ESCS). The index of ESCS was measured with questionnaires filled by students. The index of ESCS consisted of three factors: 1) highest parental education, 2) highest parental occupation, and 3) family wealth. Parental education was classified into 7 categories ranging from 0 (no education) to 6 
(theoretically oriented tertiary and post-graduate) in accord with the International Standard Classification of Education (ISCED) 1997 (OECD, 1999). Parental occupation was classified on the basis of the International Standard Classification of Occupations (ISCO-08). Family wealth was evaluated with 19 household items measuring, for example, the availability of books, electronic device, works of art, and room space at home environment. The index of ESCS was scaled so that the score of an average OECD student was 0 and the standard deviation across the OECD countries was 1 . The statistical estimation of the index of ESCS is described more precisely elsewhere (OECD, 2017a).

\subsection{Statistical Analyses}

The data were analyzed using generalized structural equation models. The models were conducted using generalized SEM in STATA SE version 13.0. We conducted separate structural equation models for each cognitive learning outcome (i.e. scientific literacy, mathematical literacy, reading literacy, and collaborative problem-solving). Students' performance in each cognitive learning outcome was treated as latent factor with 10 plausible values, which were based on Rasch Model, as indicator (manifest) variables. The estimation of the plausible values is described more precisely elsewhere (OECD, 2017a).

In models 1 , we predicted each cognitive learning outcome by the categorized variable of early childhood education and care $(1=$ preschool at 6 years of age only; 2 preschool at 6 years of age and early childhood education started between 3 - 5 years of age; $3=$ preschool at 6 years of age and early childhood care started before 3 years of age). The models were adjusted for age, gender, and the index of ESCS. In models 2, we investigated whether the association of early childhood education and care with cognitive learning outcomes might be modified by parental socioeconomic status (the index of ESCS). That is, in models 2, the index of ESCS and its interaction with 3-class variable of early childhood education and care were added to the model. Age and gender were controlled for.

As additional analyses, we predicted each cognitive learning outcome by the continuous variable of starting age at early childhood education and care (ranging from 1 to 6 years of age). Child's starting age at entry into early childhood education and care was treated as a categorical variable because the association of child's age at entry in early education with later outcomes was not hypothesized to be linear. The models were adjusted for age, gender, and the index of ESCS.

In all the models, the variables of early childhood education and care, age, gender, and the index of ESCS were treated as observed variables.

\section{Results}

Descriptive statistics of the study variables are shown in Table 1 . The study sample included 2365 (51\%) female and 2269 (49\%) male students. Parental 
Table 1. Means, frequencies, standard deviations, and ranges of the study variables.

\begin{tabular}{cccc}
\hline & $\begin{array}{c}\text { Mean/Frequency } \\
(\%)\end{array}$ & SD & Range \\
Age & 15.73 & 0.28 & $15.25 ; 16.25$ \\
Gender & & & \\
Female & $2365(51.0)$ & & \\
Male & $2269(49.0)$ & & \\
Parental socioeconomic status & 0.29 & 0.73 & $-2.91 ; 2.91$ \\
Early childhood education and care & & & \\
Preschool at 6 years of age & $852(18.4)$ & & \\
Preschool at 6 years of age and early childhood \\
education started in 3 - 5 years of age
\end{tabular}

${ }^{1}$ The mean of the plausible values $1-10$.

socioeconomic status (the index of ESCS) was scaled so that the score of an average OECD student was 0 and the standard deviation across the OECD countries was 1 . In our sample, the index of ESCS was on average 0.29 , i.e. slightly higher than the average of the OECD countries. Regarding early childhood education, the mean starting age at early childhood education was approximately 3.9 years. Furthermore, $18.4 \%$ of the participants had been only in preschool at 6 years of age; $62.2 \%$ had started in early childhood education at 3 - 5 years of age, and $19.4 \%$ of the participants had started in early childhood education before 3 years of age.

Table 2 presents the results of structural equation models, when predicting cognitive learning outcomes by the 3-class variable of early childhood education and care. Before Bonferroni-correction, we obtained only one significant association. That is, students who had participated in early childhood education before 3 years of age performed slightly better in mathematical literacy ( $B=7.96,95 \%$ $\mathrm{CI}=1.49-14.43, p=0.016$ ), when compared to participants who had only participated in preschool at 6 years of age (see Table 2). After Bonferroni-correction, however, this association was non-significant. In any other cognitive learning outcome (i.e. scientific literacy, reading literacy, or collaborative problem-solving), students who had only participated in preschool at 6 years of age did not differ from 1) students who had participated in preschool at 6 years of age and started in early childhood education at $3-5$ years of age or 2) students who had 
Table 2. The regression coefficients (B) with $95 \%$ confidence intervals (CI) of structural equation models, when predicting cognitive learning outcomes by participation in early childhood education and care (categorical variable).

\begin{tabular}{|c|c|c|c|c|c|c|c|c|}
\hline & \multicolumn{8}{|c|}{ Cognitive learning outcomes } \\
\hline & \multicolumn{2}{|c|}{ Scientific literacy } & \multicolumn{2}{|c|}{ Mathematical literacy } & \multicolumn{2}{|c|}{ Reading literacy } & \multicolumn{2}{|c|}{$\begin{array}{c}\text { Collaborative } \\
\text { problem-solving }\end{array}$} \\
\hline & B & $95 \%$ CI & B & $95 \%$ CI & B & $95 \%$ CI & B & $95 \%$ CI \\
\hline Age & $14.58^{\star *}$ & $6.01 ; 23.14$ & $11.07^{\star \star}$ & $4.17 ; 17.98$ & $15.62^{* * *}$ & $8.08 ; 23.16$ & $16.79^{* * *}$ & $8.47 ; 25.10$ \\
\hline Gender $^{1}$ & $-15.45^{\star * *}$ & $-20.33 ;-10.58$ & --3.05 & $-6.98 ; 0.88$ & $-41.42^{* * *}$ & $-45.73 ;-37.10$ & $-45.71^{\star * *}$ & $-50.49 ;-40.93$ \\
\hline Index of ESCS & $38.56^{* * *}$ & $35.20 ; 41.92$ & $35.12^{* * *}$ & $32.39 ; 37.86$ & $34.63^{\star * *}$ & $31.66 ; 37.60$ & $29.87^{\star * *}$ & $26.60 ; 33.15$ \\
\hline \multicolumn{9}{|l|}{$\begin{array}{l}\text { Early childhood education and } \\
\text { care }\end{array}$} \\
\hline Preschool at 6 years of age ${ }^{2}$ & - & - & - & - & - & - & - & - \\
\hline $\begin{array}{l}\text { Preschool at } 6 \text { years of age and } \\
\text { early childhood education } \\
\text { started in } 3 \text { - } 5 \text { years of age }\end{array}$ & -3.91 & $-10.41 ; 2.59$ & 0.86 & $-4.38 ; 6.10$ & -3.54 & $-9.26 ; 2.19$ & -2.60 & $-8.90 ; 3.71$ \\
\hline $\begin{array}{l}\text { Preschool at } 6 \text { years of age and } \\
\text { early childhood care started } \\
\text { before } 3 \text { years of age }\end{array}$ & 3.81 & $-4.21 ; 11.84$ & $7.96^{*}$ & $1.49 ; 14.43$ & 4.45 & $-2.62 ; 11.51$ & 2.36 & $-5.43 ; 10.15$ \\
\hline
\end{tabular}

participated in preschool at 6 years of age and started in early childhood care before 3 years of age. These associations were controlled for age, gender, and the index of ESCS.

Table 3 shows the results of structural equation models, when investigating the modifying effect of the index of ESCS on the association of early childhood education and care with cognitive learning outcomes. We found that when predicting students' performance in scientific literacy, there was a significant positive interaction effect between the index of ESCS and early childhood education and care $(\mathrm{B}=11.29, p=0.047)$. However, this association was non-significant after Bonferroni-correction. In any other cognitive learning outcome, we did not obtain any significant modifying effect of the index of ESCS on the association of early childhood education and care with any cognitive learning outcome. Overall, at a trend level, the findings suggested that participation in early education and care before preschool (6 years of age) appeared to be more beneficial for cognitive learning outcomes at 15 years of age among students with higher than lower index of ESCS (i.e. parental SES). This is illustrated in Figures 1-4.

As additional analyses, we investigated whether the unclassified variable of child's starting age at early childhood education and care might be linked with cognitive learning outcomes. The results are shown in Table A1. It was found that students who had started in early childhood care at 2 years of age performed slightly better in mathematical literacy at 15 years of age, when compared to participants who had only participated in preschool at 6 years of age $(\mathrm{B}=8.48, p=$ $0.015)$. Additionally, students who had started in early childhood education at 5 years of age had slightly weaker performance in reading literacy, when compared to students who had only participated in preschool $(\mathrm{B}=-8.62, p=0.014)$. 
Table 3. The regression coefficients (B) with 95\% confidence intervals (CI) of structural equation models, when predicting cognitive learning outcomes by participation in early childhood education and care and the index of ESCS.

\begin{tabular}{|c|c|c|c|c|c|c|c|c|}
\hline & \multicolumn{8}{|c|}{ Cognitive learning outcomes } \\
\hline & \multicolumn{2}{|c|}{ Scientific literacy } & \multicolumn{2}{|c|}{ Mathematical literacy } & \multicolumn{2}{|c|}{ Reading literacy } & \multicolumn{2}{|c|}{$\begin{array}{c}\text { Collaborative } \\
\text { problem-solving }\end{array}$} \\
\hline & B & $95 \% \mathrm{CI}$ & B & $95 \% \mathrm{CI}$ & B & $95 \% \mathrm{CI}$ & B & $95 \% \mathrm{CI}$ \\
\hline Age & $14.73^{* *}$ & $6.17 ; 23.30$ & $11.15^{\star *}$ & $4.24 ; 18.05$ & $15.72^{\star * *}$ & $8.17 ; 23.26$ & $16.80^{\star * *}$ & $8.48 ; 25.11$ \\
\hline $\begin{array}{l}\text { Gender }^{1} \\
\text { Early childhood education } \\
\text { and care }\end{array}$ & $-15.45^{* * *}$ & $-20.32 ;-10.57$ & $-3.01^{\star}$ & $-6.94 ; 0.92$ & $-41.43^{* * *}$ & $-45.75 ;-37.11$ & $-45.68^{* * *}$ & $-50.46 ;-40.90$ \\
\hline Preschool at 6 years of age ${ }^{2}$ & - & - & - & - & - & - & - & - \\
\hline $\begin{array}{l}\text { Preschool at } 6 \text { years of age } \\
\text { and early childhood education } \\
\text { started in } 3 \text { - } 5 \text { years of age }\end{array}$ & -4.05 & $-10.65 ; 2.55$ & 1.13 & $-4.19 ; 6.45$ & -3.75 & $-9.56 ; 2.06$ & -2.34 & $-8.74 ; 4.07$ \\
\hline $\begin{array}{l}\text { Preschool at } 6 \text { years of age } \\
\text { and early childhood care } \\
\text { started before } 3 \text { years of age }\end{array}$ & 0.32 & $-8.43 ; 9.06$ & 4.60 & $-2.45 ; 11.65$ & 3.07 & $-4.63 ; 10.77$ & 0.85 & $-7.64 ; 9.34$ \\
\hline Index of ESCS & $34.10^{* * *}$ & $26.28 ; 41.92$ & $33.18^{* * *}$ & $26.87 ; 39.50$ & $31.94^{\star * *}$ & $25.05 ; 38.84$ & $29.78^{\star * *}$ & $22.18 ; 37.38$ \\
\hline $\begin{array}{c}\text { Index of ESCS }{ }^{\star} \text { Early childhood } \\
\text { education and care }\end{array}$ & & & & & & & & \\
\hline $\begin{array}{l}\text { Index of ESCS }{ }^{\star} \text { Preschool } \\
\text { at } 6 \text { years of age }\end{array}$ & - & - & - & - & - & - & - & - \\
\hline $\begin{array}{l}\text { Index of ESCS }{ }^{\star} \text { Preschool at } \\
6 \text { years of age and early } \\
\text { childhood education } \\
\text { started in } 3 \text { - } 5 \text { years of age }\end{array}$ & 3.85 & $-5.01 ; 12.71$ & 0.57 & $-6.57 ; 7.72$ & 2.75 & $-5.05 ; 10.55$ & -0.78 & $-9.38 ; 7.82$ \\
\hline $\begin{array}{l}\text { Index of ESCS* Preschool at } \\
6 \text { years of age and early } \\
\text { childhood care started } \\
\text { before } 3 \text { years of age }\end{array}$ & $11.29^{*}$ & $0.15 ; 22.44$ & 8.89 & $-0.093 ; 17.88$ & 5.22 & $-4.59 ; 15.03$ & 3.35 & $-7.47 ; 14.16$ \\
\hline
\end{tabular}

${ }^{* * *} p<0.001,{ }^{* *} p<0.01,{ }^{*} p<0.05$. ${ }^{\mathrm{a}}$ The reference group. $N=4634 .{ }^{1}$ Girls as the reference group. ${ }^{2}$ The reference group.

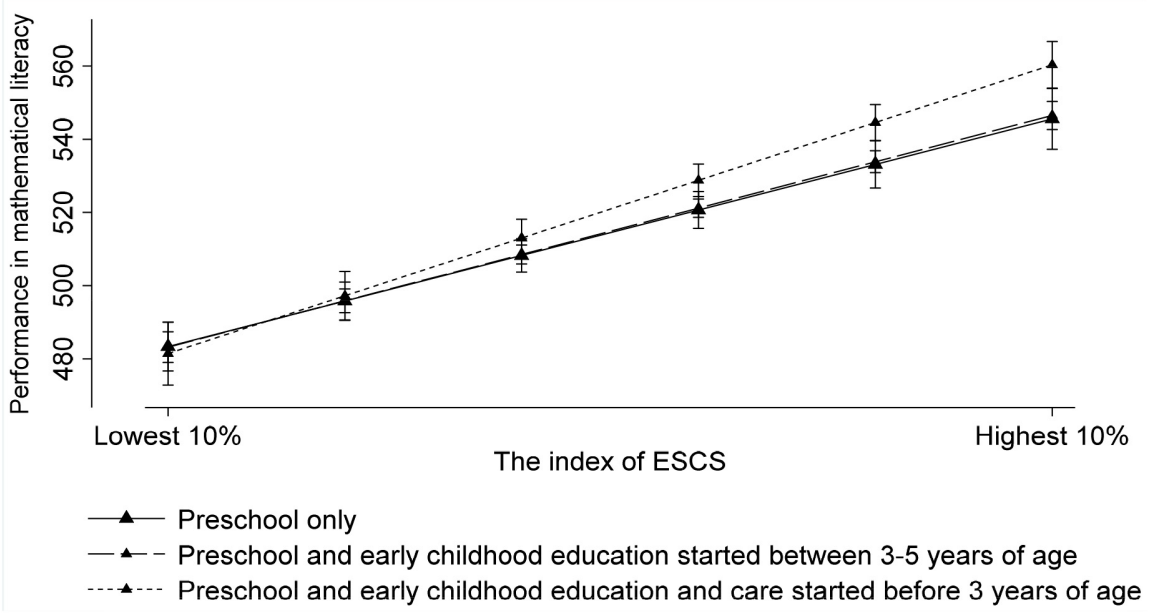

Figure 1. Predicted means with 95\% confidence intervals of students' performance in mathematical literacy at different levels of the index of ESCS and separately for students with different exposure to early childhood education and care. Note: we used the mean of the plausible values 1 - 10 of cognitive learning outcomes in this Figure. 


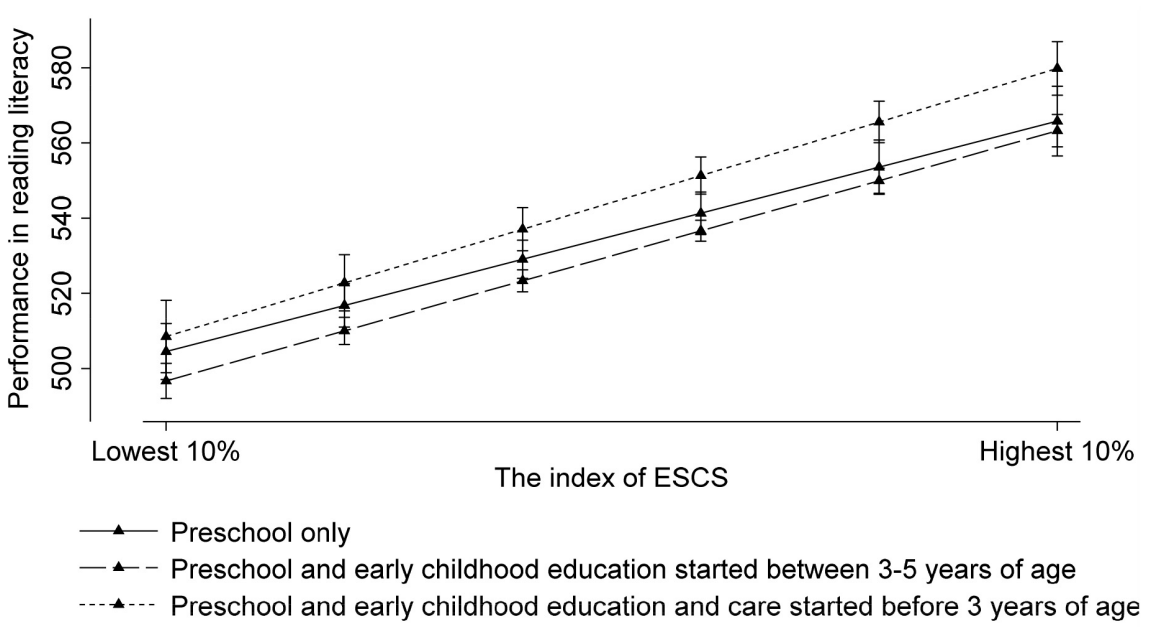

Figure 2. Predicted means with $95 \%$ confidence intervals of students' performance in reading literacy at different levels of the index of ESCS and separately for students with different exposure to early childhood education and care. Note: we used the mean of the plausible values 1 - 10 of cognitive learning outcomes in this Figure.

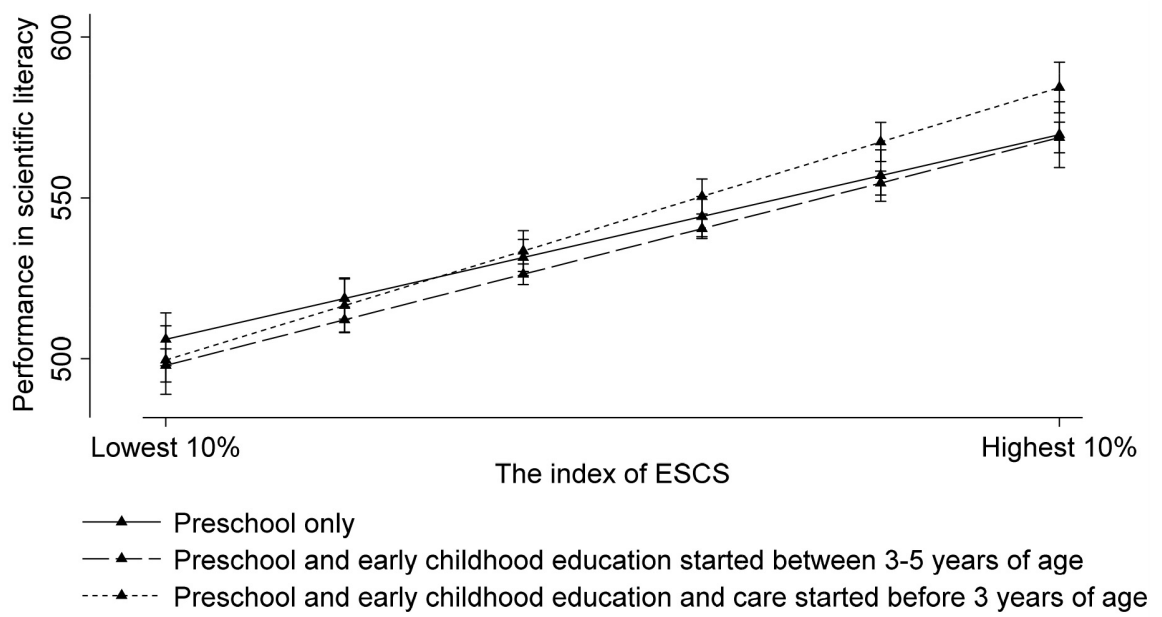

Figure 3. Predicted means with $95 \%$ confidence intervals of students' performance in scientific literacy at different levels of the index of ESCS and separately for students with different exposure to early childhood education and care. Note: we used the mean of the plausible values 1 - 10 of cognitive learning outcomes in this Figure.

After Bonferroni-correction, these associations was non-significant. Taken together, after Bonferroni-correction, students who had only participated in preschool at 6 years of age did not differ in any cognitive learning outcome from students who had started in early childhood education and care at any other age between $1-5$ years.

\section{Discussion}

The present study investigated the association of early childhood education and care with cognitive learning outcomes at 15 years of age in Finland. In any cognitive learning outcome (i.e. scientific literacy, reading literacy, or collaborative 


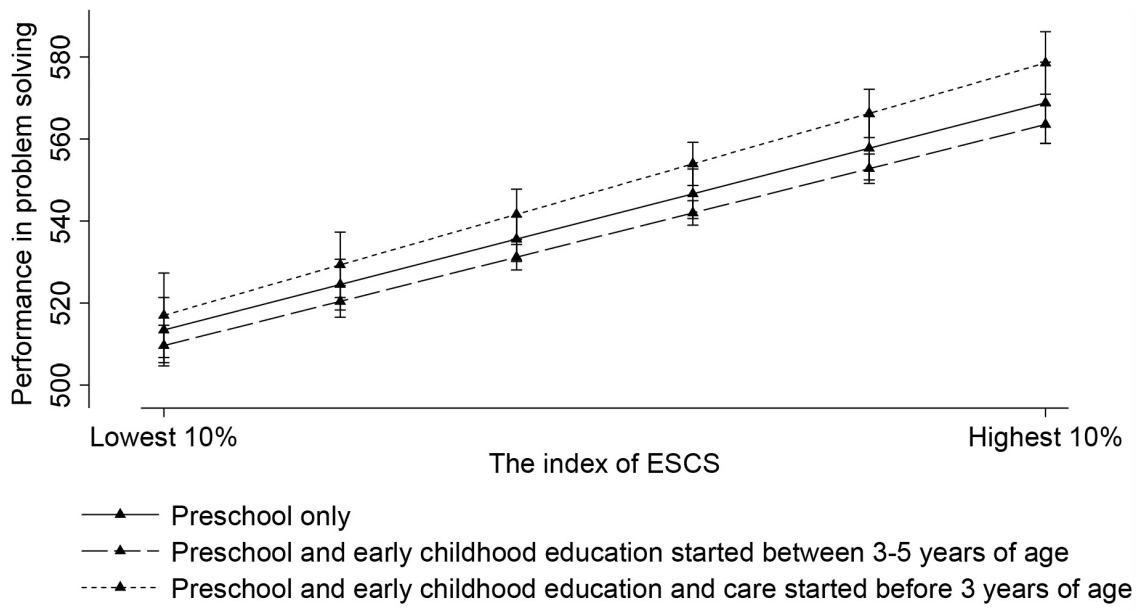

Figure 4. Predicted means with $95 \%$ confidence intervals of students' performance in collaborative problem solving at different levels of the index of ESCS and separately for students with different exposure to early childhood education and care. Note: we used the mean of the plausible values 1 - 10 of cognitive learning outcomes in this Figure.

problem-solving), students who had only participated in preschool at 6 years of age did not differ from 1) students who had participated in preschool at 6 years of age and started in early childhood education at 3 - 5 years of age or 2) students who had participated in preschool at 6 years of age and started in early childhood care before 3 years of age. Consequently, early childhood education and care was not associated with cognitive learning outcomes at 15 years of age. All these associations were controlled for age, gender, and the index of ESCS (i.e. parental socioeconomic status). Secondly, we treated child's starting age in early childhood education and careas unclassified variable. It was found that students who had started in early childhood education and care at 6 years of age (preschool) did not differ in any cognitive learning outcome from students who had started in early childhood education and care at any other age between 1 - 5 years. Additionally, at a trend level, we found that participation in early childhood education and care before preschool (6 years of age) appeared to be more beneficial for cognitive learning outcomes at 15 years of age among students with high parental SES than low parental SES. Hence, participation in early childhood education and care before preschool did not increase the equality in the learning outcomes between students coming from different socioeconomic family backgrounds.

Previous studies have indicated that the beneficial effects of early childhood education on cognitive achievements may be mostly temporary. For example, there is evidence that participation in early childhood care is not linked to reading or math skills after 1 year from the end of early childhood education (Votruba-Drzal et al., 2008), cognitive achievements at the age of $7-8$ years (Han et al., 2001) or 11 years (Esping-Andersen et al., 2012), or behavioral adjustment at 6th grade (Colwell et al., 2001). In line with these findings, we found that participation in early childhood education and care before preschool (i.e. 
before 6 years of age) was not related to cognitive learning outcomes at 15 years of age. Consequently, it may be that participation in early childhood education increases the child's school readiness or ability to perform in testing conditions, rather than the child's cognitive abilities per se. For example, early childhood care is found to predict higher adjustment to school routines (Andersson, 1996), higher level of communicational skills (Connell \& Prinz, 2002), and better self-control in class environment (Berlinski et al., 2009). Taken together, early childhood education and care may improve the child's adaptation to the classroom environment and, in that way, improve the child's learning achievements during the first school years, but not cognitive performance in later years. This study showed that participation in early childhood education and care was not linked with cognitive learning outcomes at 15 years of age in Finland.

Our findings suggest that early childhood education and care before preschool (i.e. before 6 years of age) may not increase equality in cognitive learning outcomes between students coming from different socioeconomic backgrounds. Instead, contrary to previous suggestions (e.g. Lundqvist, 2007), the effect of early childhood education and care on cognitive learning outcomes appeared to be slightly more beneficial among students with high parental SES than low parental SES. Overall, this indicates that such an early childhood education and care, which is provided for the whole age group and which follows the same curriculum, may not increase equality in the later school achievements in Finland. Instead, it may benefit children differentially, depending on their family background and the skills that have been achieved at home and may increase child's adaptability to the early childhood care environment.

This is in line with several previous studies indicating that early childhood care may fail to deliver any compensatory effects on cognitive or socioemotional development among children coming from high-risk families (e.g. Ceci \& Papierno, 2005; NICHD, 2002b, 2005). Some studies, nevertheless, have suggested that child care might have more positive effects on cognitive outcomes among children with disadvantaged family backgrounds (e.g. Geoffroy et al., 2007; Melhuish et al., 2008; Peisner-Feinberg et al., 2001). Overall, it seems that parental SES may differentially modify the effect of early childhood care on child's cognitive achievements across different countries.

In other countries than Finland, the association of low family SES with child's poorer cognitive development is found to proceed via a range of pathways. For example, it has been found that children with economically disadvantaged backgrounds have fewer learning and recreational materials available (Bradley \& Corwyn, 2002). Moreover, they are more likely to have inadequate access to health care services in childhood (Bradley \& Corwyn, 2002; Bradley \& Whiteside-Mansell, 1997; Guo \& Harris, 2000; Scholer et al., 1999), and also their mothers have weaker availability of maternity care during pregnancy (Crooks, 1995). Finally, there is evidence that socioeconomic risk factors are linked to a lower level of hygiene, impaired immune system functioning, and poorer resis- 
tance against infections (Korenman \& Miller, 1997; McEwen \& Seeman, 1999; US Department of Health \& Human Services, 2000). In Finland, however, most of these pathways from low parental SES to child development may not likely exist. That is, all the Finnish children have the access to the full range of public health care services, and the general level of hygiene is high (e.g. WHO, 2010). Moreover, maternity care is free and used by almost the entire population of Finnish pregnant women, regardless of socioeconomic factors (Official Statistics of Finland, 2017). Additionally, there are libraries and a variety of hobby clubs that are particularly targeted for children coming from socioeconomically disadvantaged families.

In the present study, we found that at a trend level, participation in early childhood education and care before 6 years of age seemed to have slightly more beneficial effects on cognitive learning outcomes at 15 years of age among students with high parental SES than low parental SES. Previously, it has been stated that a range of socioemotional qualities are required from the child to adapt to the early childhood care environment (e.g. Datler et al., 2012). Such qualities include, for example, social and self-regulation skills, ability to attach securely to caretakers, ability to express signs of distress and ask for emotional support from caregivers, and explorative interest in ongoing group activities (Ahnert et al., 2004; Datler et al., 2012; Howes \& Smith, 1995). Among children with high parental SES, these qualities are likely more appropriately developed (e.g. Bradley \& Corwyn, 2012). Hence, it may be that children coming from socioeconomically favorable families have better abilities to adapt to early childhood education and care.

Overall, it needs to be taken into consideration that the index of ESCS (parental SES) may include heterogeneous combinations of single socioeconomic factors. Specifically, even though parental socioeconomic factors generally are strongly correlated, in some cases mother's and father's educational level and occupational status may substantially differ from each other. Further, mother's and father's socioeconomic status may differentially affect the decisions about when to take the child into early childhood education and care. For example, high maternal education may likely be linked to a shorter period of maternity leave and, hence, child's earlier starting age at early childhood education and care.

Importantly, the role of child's starting age of early childhood education and care has been largely ignored in several studies. However, the child's age at entry into early childhood education and care seems to be a critical factor modifying the influence of early education on child's development. There is a great amount of evidence that entry into early childhood care during the first years of life, especially before 3 years of age, may mitigate the positive effects of early childhood care on child's development (e.g. Baydar \& Brooks-Gunn, 1991; Blau \& Grossberg, 1990; Gregg et al., 2003; Han et al., 2001; Nomaguchi et al., 2006; Ruhm, 2004). After 3 years of age, children have increasing capacity to, for example, 
engage in conversational interactions (e.g. Neuman, 2011), to express their experiences and feelings to caretakers (Painter, 1999), to maintain secure mother-child attachment despite daily separations (NICHD, 1997; Waldfogel, 2002), to engage in social role-playing in peer groups (Howes, 1994), and to self-regulate one's behavior and consciously process rules (Dowsett \& Livesey, 2000; Zelazo et al., 1996). Taken together, the age of 3 years is commonly regarded as a milestone in child's cognitive and socioemotional development, so that after 3 years of age, the child is likely to have better abilities to adapt to the early childhood education. In this study, however, participation in early education and care before or after 3 years of age was not related to better learning outcomes at 15 years of age, when compared to students who had only participated in preschool.

In the present study, there were some methodological limitations that are necessary to take into consideration. Firstly, parental socioeconomic factors were evaluated retrospectively in 2015, not in participants' childhood. However, the stability of the socioeconomic factors is found to be high in adulthood. Furthermore, the index of parental SES consisted of occupational status, educational level, and family wealth, and this multi-factorial nature of the SES index was used in order to increase its reliability. Secondly, also participation in early childhood education and care was assessed retrospectively in 2015 using questionnaires filled by parents. We did not have any child care register available, so that we could not exclude the possibility of parents' recall bias related to their child's participation in early childhood education and care. However, some previous studies have evaluated the amount of early childhood education and care even more indirectly, for example, via the number of maternal employment months (e.g. Kosonen \& Huttunen, 2018). Overall, the present study provides preliminary evidence about the association of early education and care with cognitive learning outcomes at 15 years of age in Finland. Future studies could investigate this topic using more elaborated measures of family background and early childhood education and care in Finland.

Moreover, in the PISA 2015, it was not assessed whether students had received full-time or part-time early childhood education or care. Previously, it has been demonstrated that full-time participation in non-parental care may mitigate several positive effects of early childhood care on child development (Nomaguchi et al., 2006). For example, full-day participation in child care is showed to be linked with lower school readiness at 3 years of age (Brooks-Gunn et al., 2002), attachment problems with the mother (NICHD, 1997), and higher risk for deficits in immune system and externalizing behavior (Gregg et al., 2003). Consequently, there is a need for future studies investigating whether full-day vs. half-day participation in early childhood education and care might be differentially linked with child's cognitive achievements in Finland.

This study had also a variety of substantial strengths. Firstly, this was among the first studies to investigate the relationship of early childhood education and care with school achievements. Secondly, the PISA data includes a highly repre- 
sentative sample of the Finnish 15-years students around the country. Hence, the results can probably be generalized nation-widely to various districts of Finland. Thirdly, we had an internationally standardized set of cognitive learning outcomes, including four most central learning domains (i.e. science, mathematics, reading, collaborative problem-solving). Finally, the PISA data enabled us to investigate the modifying role of family background on the association of early childhood education and care with cognitive learning outcomes.

\section{Conclusion}

Our findings suggested that participation in early childhood education and care before preschool (i.e. before 6 years of age) in 2001-2007 is not related to performance in scientific literacy, mathematical literacy, reading literacy, or collaborative problem-solving at 15 years of age in Finland. Moreover, our results did not provide support for the previous suggestions that early childhood education or care might be more beneficial for children coming from socioeconomically disadvantaged families in Finland. Currently, one goal of the Finnish government is to enhance children's participation rate in early childhood education and care (Ministry of Education and Culture, 2016). The implementation of this decision would require extensive economic investments and, hence, should be firmly based on evidence. Our findings, however, indicate that such an early childhood education and care, which is provided for the whole age group and which follows the same curriculum, has failed to promote learning outcomes at 15 years of age and to increase equality in the later school achievements in Finland.

\section{Fund}

This research did not receive any specific grant from funding agencies in the public, commercial, or not-for-profit sectors.

\section{Conflicts of Interest}

The authors declare no conflicts of interest regarding the publication of this paper.

\section{References}

Andersson, B. E. (1996). Children's Development Related to Day-Care, Type of Family and Other Home Factors. European Child \& Adolescent Psychiatry, 5, 73-75. https://doi.org/10.1007/BF00538549

Baydar, N., \& Brooks-Gunn, J. (1991). Effects of Maternal Employment and Child-Care Arrangements on Preschoolers' Cognitive and Behavioral Outcomes: Evidence from the Children of the National Longitudinal Survey of Youth. Developmental Psychology, 27, 932-945. https://doi.org/10.1037/0012-1649.27.6.932

Berlinski, S., Galiani, S., \& Gertler, P. (2009). The Effect of Pre-Primary Education on Primary School Performance. Journal of Public Economics, 93, 219-234. https://doi.org/10.1016/j.jpubeco.2008.09.002 
Blau, F. D., \& Grossberg, A. J. (1990). Maternal Labor Supply and Children's Cognitive Development (No. w3536). National Bureau of Economic Research. https://doi.org/10.3386/w3536

Bradley, R. H., \& Corwyn, R. F. (2002). Socioeconomic Status and Child Development. Annual Review of Psychology, 53, 371-399. https://doi.org/10.1146/annurev.psych.53.100901.135233

Bradley, R. H., \& Whiteside-Mansell, L. (1997). Children in Poverty. In R. T. Ammerman, \& M. Hersen (Eds.), Handbook of Prevention and Treatment with Children and Adolescents (p. 1358). New York: Wiley.

Broberg, A. G., Wessels, H., Lamb, M. E., \& Hwang, C. P. (1997). Effects of Day Care on the Development of Cognitive Abilities in 8-Year-Olds: A Longitudinal Study. Developmental Psychology, 33, 62-69. https://doi.org/10.1037/0012-1649.33.1.62

Brooks-Gunn, J., Han, W. J., \& Waldfogel, J. (2002). Maternal Employment and Child Cognitive Outcomes in the First Three Years of Life: The NICHD Study of Early Child Care. Child Development, 73, 1052-1072. https://doi.org/10.1111/1467-8624.00457

Burchinal, M. R., Roberts, J. E., Riggins Jr., R., Zeisel, S. A., Neebe, E., \& Bryant, D. (2000). Relating Quality of Center-Based Child Care to Early Cognitive and Language Development Longitudinally. Child Development, 71, 339-357. https://doi.org/10.1111/1467-8624.00149

Ceci, S. J., \& Papierno, P. B. (2005). The Rhetoric and Reality of Gap Closing: When the "Have Nots" Gain but the "Haves" Gain Even More. American Psychologist, 60, 149-160. https://doi.org/10.1037/0003-066X.60.2.149

Colwell, M. J., Pettit, G. S., Meece, D., Bates, J. E., \& Dodge, K. A. (2001). Cumulative Risk and Continuity in Nonparental Care from Infancy to Early Adolescence. Merrill-Palmer Quarterly, 47, 207. https://doi.org/10.1353/mpq.2001.0009

Connell, C. M., \& Prinz, R. J. (2002). The Impact of Childcare and Parent-Child Interactions on School Readiness and Social Skills Development for Low-Income African American Children. Journal of School Psychology, 40, 177-193. https://doi.org/10.1016/S0022-4405(02)00090-0

Crooks, D. L. (1995). American Children at Risk: Poverty and Its Consequences for Children's Health, Growth, and School Achievement. American Journal of Physical Anthropology, 38, 57-86. https://doi.org/10.1002/ajpa.1330380605

Datler, W., Ereky-Stevens, K., Hover-Reisner, N., \& Malmberg, L. E. (2012). Toddlers' Transition to Out-of-Home Day Care: Settling into a New Care Environment. Infant Behavior and Development, 35, 439-451. https://doi.org/10.1016/j.infbeh.2012.02.007

Dowsett, S. M., \& Livesey, D. J. (2000). The Development of Inhibitory Control in Preschool Children: Effects of "Executive Skills" Training. Developmental Psychobiology: The Journal of the International Society for Developmental Psychobiology, 36, 161-174. https://doi.org/10.1002/(SICI)1098-2302(200003)36:2<161::AID-DEV7>3.0.CO;2-0

Early Childhood Education Legislation (1973/36). https://www.finlex.fi/fi/laki/ajantasa/1973/19730036

Esping-Andersen, G., Garfinkel, I., Han, W. J., Magnuson, K., Wagner, S., \& Waldfogel, J. (2012). Child Care and School Performance in Denmark and the United States. Children and Youth Services Review, 34, 576-589. https://doi.org/10.1016/j.childyouth.2011.10.010

Geoffroy, M. C., Côté, S. M., Borge, A. I., Larouche, F., Séguin, J. R., \& Rutter, M. (2007). Association between Nonmaternal Care in the First Year of Life and Children's Receptive Language Skills Prior to School Entry: The Moderating Role of Socioeconomic 
Status. Journal of Child Psychology and Psychiatry, 48, 490-497.

https://doi.org/10.1111/j.1469-7610.2006.01704.x

Gregg, P., Washbrook, E., \& ALSPAC Study Team (2003). The Effects of Early Maternal Employment on Child Development in the UK. University of Bristol CMPO Discussion Paper 3, 70.

Guo, G., \& Harris, K. M. (2000). The Mechanisms Mediating the Effects of Poverty on Children's Intellectual Development. Demography, 37, 431-447. https://doi.org/10.1353/dem.2000.0005

Han, W. J., Waldfogel, J., \& Brooks-Gunn, J. (2001). The Effects of Early Maternal Employment on Later Cognitive and Behavioral Outcomes. Journal of Marriage and Family, 63, 336-354. https://doi.org/10.1111/j.1741-3737.2001.00336.x

Hiilamo, H., Merikukka, M., \& Haataja, A. (2018). Long-Term Educational Outcomes of Child Care Arrangements in Finland. SAGE Open, 8, 2158244018774823. https://doi.org/10.1177/2158244018774823

Howes, C. (1994). The Collaborative Construction of Pretend. Albany: State University of New York Press.

Jakku-Sihvonen, R., \& Kuusela, J. (2002). Mahdollisuuksien koulutuspolitiikan tasa-arvo. Arviointi 7/2002, Opetushallitus. Helsinki: Yliopistopaino.

Karhula, A., Erola, J., \& Kilpi-Jakonen, E. (2017). Home Sweet Home? Long-Term Educational Outcomes of Childcare Arrangements in Finland (p. 268). Cheltenham: Edward Elgar Publishing.

Korenman, S., \& Miller, J. E. (1997). Effects of Long-Term Poverty on Physical Health of Children in the National Longitudinal Survey of Youth. In G. J. Duncan, \& J. Brooks-Gunn (Eds.), Consequences of Growing Up Poor (pp. 70-99). New York: Russell Sage Foundation.

Kosonen, T., \& Huttunen, K. (2018). Kotihoidon tuen vaikutus lapsiin. Labor Institute for Economic Research, Studies 115.

Lundqvist, A. (2007). Familjen i den svenska modellen. Umea: Borea.

Magnuson, K. A., Ruhm, C., \& Waldfogel, J. (2007). Does Prekindergarten Improve School Preparation and Performance. Economics of Education Review, 26, 33-51. https://doi.org/10.1016/j.econedurev.2005.09.008

Melhuish, E. C., Sylva, K., Sammons, P., Siraj-Blatchford, I., Taggart, B., Phan, M., \& Malin, A. (2008). Preschool Influences on Mathematics Achievement. Science, 321, 11611162. https://doi.org/10.1126/science. 1158808

Ministry of Education and Culture (2016). Hallituksen esitys 60/2016. Hallituksen esitys eduskunnalle laeiksi varhaiskasvatuksen asiakasmaksuista sekä varhaiskasvatuslain 13 S:n ja sosiaali-ja terveydenhuollon asiakasmaksuista annetun lain muuttamisesta.

Mol, S., Bus, A., de Jong, M., \& Smeets, D. (2008). Added Value of Dialogic Parent-Child Book Readings: A Meta-Analysis. Early Education and Development, 19, 7-26. https://doi.org/10.1080/10409280701838603

Määttä, K., \& Uusiautti, S. (2012). How Do the Finnish Family Policy and Early Education System Support the Well-Being, Happiness, and Success of Families and Children. Early Child Development and Care, 182, 291-298. https://doi.org/10.1080/03004430.2011.646718

Neuman, S. B. (2011). The Challenge of Teaching Vocabulary in Early Education. In S. B. Neuman, \& D. D. Dickinson (Eds.), Handbook of Early Literacy Research (Vol. 3, pp. 358-372). New York: Guilford.

NICHD Early Child Care Research Network (1997). The Effects of Infant Child Care on 
Infant-Mother Attachment Security: Results of the NICHD Study of Early Child Care. Child Development, 68, 860-879. https://doi.org/10.1111/j.1467-8624.1997.tb01967.x

NICHD Early Child Care Research Network (2002a). Early Child Care and Children's Development Prior to School Entry: Results from the NICHD Study of Early Child Care. American Educational Research Journal, 39, 133-164.

NICHD Early Child Care Research Network (2002b). The Interaction of Child Care and Family Risk in Relation to Child Development at 24 and 36 Months. Applied Developmental Science, 6, 144-156.

NICHD Early Child Care Research Network (2005). Early Child Care and Children's Development in the Primary Grades: Results from the NICHD Study of Early Child Care. American Educational Research Journal, 43, 537-570. https://doi.org/10.3102/00028312042003537

Nomaguchi, K. M. (2006). Maternal Employment, Nonparental Care, Mother-Child Interactions, and Child Outcomes during Preschool Years. Journal of Marriage and Family, 68, 1341-1369. https://doi.org/10.1111/j.1741-3737.2006.00332.x

Official Statistics of Finland (2017). Perinatal Statistics-Parturients, Deliveries and Newborns 2016. Statistical Report 37/2017, 31.10.2017. National Institute for Health and Welfare.

Organisation for Economic Co-Operation and Development (2004). The PISA 2003 Assessment Framework: Mathematics, Reading, Science and Problem Solving Knowledge and Skills. Paris: OECD Publishing.

Organisation for Economic Co-Operation and Development (2006). Assessing Scientific, Reading and Mathematical Literacy: A Framework for PISA 2006. Paris: OECD Publishing.

Organisation for Economic Co-Operation and Development (2010). PISA 2009 Assessment Framework: Key Competencies in Reading, Mathematics and Science. Paris: OECD Publishing.

Organisation for Economic Co-Operation and Development (OECD) (1999). Classifying Educational Programmes: Manual for ISCED-97 Implementation in OECD Countries. Paris: OECD Publishing.

Organisation for Economic Co-Operation and Development (OECD) (2016). PISA 2015 Results (Volume I): Excellence and Equity in Education, PISA. Paris: OECD Publishing.

Organisation for Economic Co-Operation and Development (OECD) (2017a). PISA 2015 Technical Report. Paris: OECD Publishing.

Organisation for Economic Co-Operation and Development (OECD) (2017b). PISA 2015 Assessment and Analytical Framework: Science, Reading, Mathematic, Financial Literacy and Collaborative Problem Solving. Paris: OECD Publishing.

Painter, C. (1999). Preparing for School: Developing a Semantic Style for Educational Knowledge. In F. Christie (Ed.), Pedagogy and the Shaping of Consciousness: Linguistic and Social Processes (pp. 66-87). London: Continuum.

Peisner-Feinberg, E. S., Burchinal, M. R., Clifford, R. M., Culkin, M. L., Howes, C., Kagan, S. L., \& Yazejian, N. (2001). The Relation of Preschool Child-Care Quality to Children's Cognitive and Social Developmental Trajectories through Second Grade. Child Development, 72, 1534-1553. https://doi.org/10.1111/1467-8624.00364

Rantalaiho, M. (2009). Kvoter, valgfrihet, fleksibilitet. Indre spenninger I den nordiske familliepolitikken. Köbenhavn: NIKK.

Repo, K. (2010). Families, Work and Home Care. Assessing the Finnish Child Home Care 
Allowance. Barn, 28, 43-63.

Ruhm, C. J. (2004). Parental Employment and Child Cognitive Development. Journal of Human Resources, 39, 155-192. https://doi.org/10.2307/3559009

Salmi, M. (2012). Combating Child Poverty through Measures Promoting the SocioCultural Participation of Clients of the Public Centres of Social Action/Welfare.

Shaw, S., \& Child, S. (2017). Utilising Technology in the Assessment of Collaboration: A Critique of PISA's Collaborative Problem-Solving Tasks. Research Matters: A Cambridge Assessment Publication, 24, 17.

Simola, H. (2005). The Finnish Miracle of PISA: Historical and Sociological Remarks on Teaching and Teacher Education. Comparative Education, 41, 455-470. https://doi.org/10.1080/03050060500317810

Snow, C. E., Porche, M. V., Tabors, P. O., \& Harris, S. R. (2007). Is Literacy Enough? Pathways to Academic Success for Adolescents. Baltimore, MD: Brookes.

US Department of Health and Human Services (2000). Child Health USA 2000. Washington DC: US GPO.

Waldfogel, J. (2002). Child Care, Women's Employment, and Child Outcomes. Journal of Population Economics, 15, 527-548. https://doi.org/10.1007/s001480100072

World Health Organization (WHO) (2010). World Health Statistics 2010. World Health Organization.

World Medical Association (2001). World Medical Association Declaration of Helsinki. Ethical Principles for Medical Research Involving Human Subjects. Bulletin of the World Health Organization, 79, 373-374.

Votruba-Drzal, E., Li-Grining, C. P., \& Maldonado-Carreño, C. (2008). A Developmental Perspective on Full- versus Part-Day Kindergarten and Children's Academic Trajectories through Fifth Grade. Child Development, 79, 957-978.

https://doi.org/10.1111/j.1467-8624.2008.01170.x

Zelazo, P. D., Frye, D., \& Rapus, T. (1996). An Age-Related Dissociation between Knowing Rules and Using Them. Cognitive Development, 11, 37-63.

https://doi.org/10.1016/S0885-2014(96)90027-1 


\section{Appendix}

Table A1. The regression coefficients (B) with 95\% confidence intervals (CI) of structural equation models, when predicting cognitive learning outcomes by the age of entry into early education and care.

\begin{tabular}{|c|c|c|c|c|c|c|c|c|}
\hline & \multicolumn{8}{|c|}{ Cognitive learning outcomes } \\
\hline & \multicolumn{2}{|c|}{ Scientific literacy } & \multicolumn{2}{|c|}{ Mathematical literacy } & \multicolumn{2}{|c|}{ Reading literacy } & \multicolumn{2}{|c|}{$\begin{array}{c}\text { Collaborative } \\
\text { problem-solving }\end{array}$} \\
\hline & $\mathrm{B}$ & $95 \% \mathrm{CI}$ & $\mathrm{B}$ & $95 \% \mathrm{CI}$ & $\mathrm{B}$ & $95 \% \mathrm{CI}$ & $\mathrm{B}$ & $95 \% \mathrm{CI}$ \\
\hline Age & $14.72^{\star *}$ & $6.14 ; 23.30$ & $10.91^{\star *}$ & $4.11 ; 17.72$ & $15.16^{* * *}$ & $7.61 ; 22.71$ & $16.61^{\star * *}$ & $6.21 ; 23.26$ \\
\hline Gender & $-15.24^{\star \star \star}$ & $-20.12 ;-10.35$ & -2.98 & $-6.85 ; 0.89$ & $-41.27^{\star * *}$ & $-45.59 ;-36.95$ & $-45.69^{\star * \star}$ & $-19.98 ;-10.27$ \\
\hline The index of ESCS & $38.48^{\star * *}$ & $35.10 ; 41.85$ & $34.26^{* * *}$ & $31.56 ; 36.96$ & $34.21^{* * *}$ & $31.22 ; 37.19$ & $29.72^{* * *}$ & $34.89 ; 41.60$ \\
\hline \multicolumn{9}{|l|}{ Early education and care (ECEC) } \\
\hline ECEC started at 6 years of age ${ }^{1}$ & - & - & - & - & - & - & - & - \\
\hline ECEC started at 5 years of age & -3.66 & $-11.44 ; 4.12$ & 0.89 & $-5.28 ; 7.07$ & $-8.62^{*}$ & $-15.46 ; 1.77$ & -4.70 & $-12.24 ; 2.86$ \\
\hline ECEC started at 3 years of age & -0.93 & $-8.67 ; 6.82$ & 2.57 & $-3.58 ; 8.71$ & 1.54 & $-5.27 ; 8.35$ & -0.49 & $-8.00 ; 7.02$ \\
\hline ECEC started at 2 years of age & 4.98 & $-3.79 ; 13.75$ & $8.48^{\star}$ & $1.52 ; 15.43$ & 5.82 & $-1.89 ; 13.54$ & 3.98 & $-4.53 ; 12.49$ \\
\hline ECEC started at 1 year of age & 1.31 & $-10.36 ; 12.97$ & 5.94 & $-3.31 ; 15.20$ & 1.71 & $-8.55 ; 11.97$ & -1.28 & $-12.61 ; 10.04$ \\
\hline
\end{tabular}

${ }^{\star} p<0.05 ;{ }^{* *} p<0.01 ;{ }^{* *} p<0.001 .{ }^{1}$ The reference group. $N=4634$. 